\title{
Status Kerbau Lokal Di Kecamatan Waeapo Berdasarkan Struktur Populasi dan Laju Silang Dalam
}

\section{The Status of Local Buffalo in District Waeapo Based on Population Structure and Inbreeding Rate}

\author{
$\operatorname{Rajab}^{\left.{ }^{*}\right)}$, Bercomien J. Papilaya ${ }^{1)}$, Tria F. K. Dewi ${ }^{1)}$ \\ ${ }^{1)}$ Program Studi Peternakan Jurusan Peternakan, Universitas Pattimura \\ Jl. Ir. M. Putuhena, Kampus Poka, Ambon \\ *rajab.amir@gmail.com \\ bercomien@gmail.com \\ febriana dewi@gmail.com
}

\begin{abstract}
Diterima : 14 Januari 2021
Disetujui : 19 Februari 2021

Diterbitkan : 28 Februari 2021
\end{abstract}

\begin{abstract}
Abstrak: Penelitian ini bertujuan untuk mengetahui status populasi kerbau lokal didasarkan pada struktur populasi dan laju silang dalam per generasi. Survey dilakukan pada dua desa yang masih memelihara kerbau di Kecamatan Waeapo, dan pengambilan data dengan metode sensus terhadap semua peternak kerbau. Variabel yang diamati meliputi struktur populasi, populasi aktual, populasi efektif dan laju silang dalam per generasi. Hasil penelitian menunjukkan populasi kerbau yang terdapat di Kecamatan Waeapo sebanyak 374 ekor dengan komposisi berikut anak jantan 8,56\% ; anak betina 7,49\% (1,14:1), muda jantan 11,5\% ; muda betina 10,96\% (1,05 : 1), dan dewasa jantan $18,72 \%$; dewasa betina 42,78\% (1 :2,29). Ukuran populasi aktual kerbau lokal adalah 230 ekor, dengan ukuran populasi efektif sebesar 194 ekor. Laju silang dalam (inbreeding) per generasi adalah o,26\%. Mengindikasikan bahwa belum terjadinya tekanan silang.
\end{abstract}

Kata Kunci : Struktur populasi, silang dalam, kerbau

Abstract: This research aims was to determined the population status of the local buffalo based on structure of population and inbreeding rate per generation. The survey was conducted in two villages that still maintain buffalo in Waeapo District, and data collection by census on all buffalo breeders. The variables observed included population structure, actual population, effective population and inbreeding rate per generation. The results showed that the population of buffalo in District Waeapo was 374 with the following composition: buffalo bull 8.56\% ; buffalo herds 7.49\% (1.14: 1), calf male 11.5\% ; calf female 10.96\% (1.05: 1), and 18.72\% adult males ; 42.78\% adult females (1: 2.29). The actual population size of the local buffalo is 230, with an effective population size of 194 individuals. The inbreeding rate per generation is $0.26 \%$. Indicates that there is no pressure on buffalo population.

Keywords : Population structure, inbreeding, buffalo

\section{Pendahuluan}

Kerbau lokal di provinsi Maluku terdapat hanya pada sebagian kecil lokasi yaitu kerbau Moa di pulau Moa dan sekitarnya di Kabupaten Maluku Barat Daya, dan kerbau lokal pada daerah transmigrasi di kabupaten Buru. Kecamatan Waeapo merupakan salah satu kecamatan yang ada di Kabupaten Buru yang terdiri dari 8 desa dan penduduknya umumnya merupakan transmigran. Introduksi kerbau lokal pada mulanya dimanfaatkan untuk tujuan sebagai tenaga kerja dalam membajak sawah atau alat angkutan. Adanya mekanisasi pertanian menyebabkan alih fungsi kerbau sebagai penghasil daging dan banyak dijual untuk menambah pendapatan keluarga, dan akibatnya terjadi penurunan populasinya. Penurunan populasi juga terjadi karena kurangnya perhatian pemerintah melalui kebijakan pemberian bantuan sapi potong, sehingga peternak lebih memilih mengusahakan sapi potong daripada kerbau.

Penurunan kualitas dan kuantitas ternak lokal merupakan masalah utama produksi ternak di Indonesia. Di antara kendala serius untuk suksesnya produktivitas ternak lokal adalah terus menurunnya populasi dan kualitas genetik khususnya pada kerbau, padahal perannya strategis dan penting untuk memenuhi kebutuhan konsumsi daging di Indonesia [1]. Populasi kerbau dilaporkan telah menurun hingga 3\% per tahun [2]. Kerbau merupakan salah satu jenis ternak ruminansia yang telah lama dikenal oleh 
masyarakat Indonesia. Meskipun kerbau belum banyak mendapatkan perhatian dari segi pemeliharaannya, akan tetapi kerbau merupakan salah satu ternak lokal yang memiliki sejumlah keunggulan dan memberi banyak manfaat khususnya bagi petani dan peternak [3]. Kerbau (Bubalus bubalis) memiliki kemampuan khusus dalam mencerna makanan yang berkualitas rendah untuk dapat bertahan hidup [4]. Keberadaan ternak ini telah bersatu dalam kehidupan sosial budaya di beberapa daerah di Indonesia [5].

Populasi merupakan kumpulan spesies tertentu yang mempunyai potensi untuk melakukan hubungan secara dinamis antara individu satu dengan individu lainnya atau kumpulan organisme sejenis yang hidup pada ekosistem tertentu [6][7]. Pengetahuan mengenai ukuran populasi dan laju penurunan populasi suatu rumpun ternak sangat penting untuk mengklasifikasikan status populasi ternak, selain untuk mengetahui kelimpahannya di alam [8]. Ukuran populasi juga merupakan data dasar untuk menilai kemungkinan kelangsungan atau keterancaman keberadaannya di alam, dan hal-hal lain yang berhubungan dengan manajemen hewan ternak ataupun satwa liar [9]. Salah satu tahap awal dalam program pelestarian plasma nutfah adalah menentukan status populasi ternak. Status populasi dapat ditentukan dengan menghitung jumlah ternak dewasa yang digambarkan dari jumlah betina dan jantan dewasa [10].

Struktur populasi merupakan susunan sekelompok organisme yang mempunyai spesies dengan takson tertentu serta hidup dan menempati kawasan tertentu pada waktu tertentu [11]. Pada ternak, mencakup induk, pejantan, jantan dan betina muda, serta pedet jantan dan betina, serta rasio berdasarkan jenis kelamin [12]. Struktur populasi perlu diketahui sebagai suatu parameter dalam mengatur sistem perkawinan, manajemen pemeliharaan dan mengetahui status serta jumlah populasi di peternakan rakyat [13].

Faktor lain yang erat kaitannya dengan status populasi ternak di suatu wilayah adalah laju silang dalam per generasi. Silang dalam (inbreeding) didefenisikan sebagai persilangan antar ternak yang memliki hubungan kekerabatan lebih dekat dalam populasi tempat individu tersebut berada [6]. Perkawinan silang dalam (inbreeding) pada ternak sangat besar dampaknya terhadap produktivitas ternak. Tekanan inbreeding pada ternak dapat menyebabkan penurunan performa produksi ternak, meningkatkan mortalitas dan turunnya reproduktivitas [11][14].

Penelitian ini bertujuan untuk mengetahui struktur populasi dan laju silang dalam per generasi kerbau lokal di Kecamatan Waeapo Kabupaten Buru sebagai sumber informasi tentang status populasi kerbau.

\section{Materi dan Metode}

\subsection{Materi Penelitian}

Penelitian ini dilaksanakan pada bulan Januari sampai dengan Februari 2020 dan berlokasi di Kecamatan Waeapo Kabupaten Buru. Hasil survey awal menunjukkan bahwa dari 8 Desa yang ada di Kecamatan Waeapo hanya 2 Desa yang penduduknya masih memelihara kerbau. Alat yang digunakan dalam penelitian ini meliputi alat tulis menulis, kuisioner dan kamera. Penelitian ini menggunakan metode survey dengan melakukan wawancara terhadap peternak sebagai responden penelitian. Pengambilan data pada masing-masing Desa sampel dilakukan secara sensus terhadap seluruh peternak kerbau. Data desa, jumlah peternak responden, dan jumlah ternak kerbau yang dipelihara seperti tertera pada Tabel 1.

Tabel 1. desa, jumlah peternak responden dan jumlah ternak kerbau Di Kecamatan Waeapo

\begin{tabular}{cccc}
\hline No & Desa & $\begin{array}{c}\text { Jumlah Peternak } \\
\text { (orang) }\end{array}$ & $\begin{array}{c}\text { Jumlah Ternak } \\
\text { (ekor) }\end{array}$ \\
\hline $\mathbf{1}$ & Waenetat & 33 & 194 \\
$\mathbf{2}$ & Wanareja & 20 & 180 \\
\hline & Jumlah & 53 & 374 \\
\hline
\end{tabular}

Sumber: hasil survey

\subsection{Metode Penelitian}

Metode yang digunakan dalam penelitian ini adalanh metode survey dengan cara mewawancarai peternak responden dan observasi (pengamatan) langsung di lapangan. Data yang diperoleh dalam penelitian ini terdiri dari data primer dan data skunder. Data primer adalah sumber data penelitian yang diperoleh secara langsung dari sumber aslinya yang berupa wawancara dan pengamatan. Data primer yang diamati meliputi; 1). Karakteristik populasi ternak kerbau atau struktur populasi (pejantan dewasa, betina dewasa, jantan muda, betina muda, anak kerbau), dan 2). Struktur populasi, populasi aktual, populasi efektif, laju silang dalam per generasi. Data sekunder adalah data yang diperoleh dari instansi terkait seperti BPS, dan pustaka yang relefan dengan tujuan penelitian.

Karakteristik struktur populasi ternak digunakan untuk mengetahui perbandingan jumlah ternak yang dipelihara berdasarkan jenis kelamin dan umur, di mana umur ternak kerbau terbagi atas dewasa $(>30$ bulan), muda ( $>12$ bulan -30 bulan), dan anak ( $0-12$ bulan) [15].

Data yang diperoleh dianalisis secara deskriptif maupun kuantitatif. Untuk mengetahui laju silang dalam per generasi kerbau lokal maka dihitung dengan menggunakan rumus menurut [16], yaitu : 


$$
\Delta \mathrm{F}=\frac{1}{2 N e} \text { dengan } \mathrm{Ne}=\frac{(4 N m N f)}{N m+N f}
$$

Dimana:

$\mathrm{Nm}=$ Jumlah jantan dewasa.

$\mathrm{Nf}=$ Jumlah betina dewasa.

$\mathrm{Ne}=$ Jumlah populasi efektif.

$\Delta \mathrm{F}=$ Laju inbreeding per generasi

\section{Hasil dan Pembahasan}

\subsection{Struktur Populasi}

Pengetahuan tentang struktur populasi apabila dikombinasikan dengan informasi tentang status populasi, perubahan genetik dalam populasi dapat memandu tindakan pengelolaan di masa depan, memungkinkan pengembangan strategi yang mendorong pada perbaikan genetik dan adaptasi suatu breed ternak di wilayah tertentu [11]. Investigasi terhadap jenis kelamin dan umur ternak dapat memberikan gambaran struktur populasi ternak. Struktur populasi kerbau lokal di Kecamatan Waeapo seperti tertera pada Tabel 2.

Tabel 2. Struktur populasi kerbau lokal di Kecamatan Waeapo Kabupaten Buru

\begin{tabular}{|c|c|c|c|c|}
\hline \multirow{2}{*}{ Variabel } & \multicolumn{2}{|c|}{ Desa } & \multicolumn{2}{|c|}{ Jumlah (Kecamatan Waeapo) } \\
\hline & Waenetat & Wanareja & Ekor & Persentase \\
\hline \multicolumn{5}{|l|}{ Anak (Ekor) } \\
\hline Jantan & 18 & 14 & 32 & 8,56 \\
\hline Betina & 13 & 15 & 28 & 7,49 \\
\hline \multicolumn{5}{|l|}{ Muda (Ekor) } \\
\hline Jantan & 23 & 20 & 43 & 11,50 \\
\hline Betina & 22 & 19 & 41 & 10,96 \\
\hline \multicolumn{5}{|l|}{ Dewasa (Ekor) } \\
\hline Jantan & 32 & 38 & 70 & 18,72 \\
\hline Betina & 86 & 74 & 160 & 42,78 \\
\hline Lahir (Ekor) & 27 & 30 & 57 & 15,24 \\
\hline Dijual (Ekor) & 83 & 44 & 127 & 33,96 \\
\hline Mati (Ekor) & 7 & 3 & 10 & 2,67 \\
\hline
\end{tabular}

Hasil penelitian menunjukkan populasi kerbau yang terdapat di kecamatan Waeapo sebanyak 374 ekor dengan komposisi berikut anak jantan $8,56 \%$ : anak betina $7,49 \%(1,14: 1)$, muda jantan $11,5 \%$ : muda betina $10,96 \%(1,05: 1)$, dan dewasa jantan $18,72 \%$ : dewasa betina $42,78 \%(1: 2,29)$. Persentase kerbau anak maupun muda dari total populasi yang rendah disebabkan masih rendahnya angka kelahiran kerbau, hal ini menunjukkan efisiensi kinerja reproduksi kerbau lokal juga masih rendah. Faktor penyebabnya diantaranya sistem pemeliharaan kerbau yang masih tradisonal tanpa adanya kandang, manajemen perkawinan yang masih alami [17], lingkungan tempat pemeliharaan termasuk pakan, musim dan manajemen yang diterima oleh ternak-ternak tersebut [18]. Perkawinan secara alami tanpa diatur dimana peluang kelahiran anak jantan dan betina yang sama berdampak terhadap rasio kerbau jantan dan betina baik pada ternak anak maupun muda yang tidak berbeda jauh [6].

Jumlah kerbau betina dewasa lebih dominan dari kerbau jantan dalam populasi karena dimanfaatkan sebagai sumber bibit untuk mempertahankan dan memperbanyak populasi, sedangkan kerbau jantan sebagian besar dijual untuk menambah pendapatan peternak dan sisanya dijadikan sumber pejantan. Sedikitnya jumlah kerbau jantan dewasa juga akibat mekanisasi pertanian dimana fungsi kerbau untuk tenaga kerja seperti membajak sawah telah digantikan oleh traktor.

Jumlah kerbau yang lahir adalah sebanyak 57 ekor atau $15,24 \%$ dari total populasi dan 35,63\% dari jumlah betina dewasa. Angka ini masih tergolong rendah bila dibanding dengan hasil penelitian Budiarto \& Ciptadi (2018) dimana angka kelahiran kerbau di Malang, Jawa Timur sebesar 20,43\% dari populasi [19], atau Marsudi dkk. (2017) dengan angka kelahiran kerbau di Lembah Napu, Poso sebesar 21,54\% dari populasi [20]. Rendahnya angka kelahiran kerbau disebabkan oleh sistem pemeliharaan yang masih tradisonal berdampak terhadap tidak adanya kontrol terhadap sistem penyapihan gudel dan perkawinan ternak dibiarkan pada alam, yang berpengaruh terhadap lambatnya siklus reproduksi induk kerbau [21].

Jumlah kerbau yang dijual sebanyak 127 ekor atau 33,96\% dari total populasi 374 ekor. Kerbau dijual karena kebutuhan ekonomi keluarga peternak. Adapun jumlah kerbau yang mati sebanyak to ekor atau 2,67\% dari total populasi. Angka kematian kerbau di Kecamatan Waeapo masih lebih rendah dibanding kerbau di Lembah Napu, Poso sebesar 3,08\% dari populasi [20]. Kematian pada kerbau disebabkan sistem pemeliharaan yang kurang baik 
(ekstensif), dimana ternak kerbau yang dipelihara kurang dalam pengontrolan.

Status populasi dapat ditentukan dengan menghitung jumlah ternak dewasa yang digambarkan dari jumlah betina dewasa dan jumlah populasi efektif [10]. Secara umum kelahiran ternak akan menambah jumlah populasi kerbau sedangkan kematian dan penjualan ternak menyebabkan penurunan jumlah populasi. Jumlah ternak yang dijual dan yang mati lebih tinggi dibandingkan dengan jumlah ternak yang lahir, menyebabkan penurunan populasi kerbau di Kecamatan Waeapo. Perbaikan manajemen pemeliharaan dan pengelolaan reproduksi melalui seleksi calon induk dan pejantan serta pengaturan perkawinan perlu dilakukan dalam upaya peningkatan populasi ternak kerbau, dengan mencegah terjadinya silang dalam (inbreeding).

\subsection{Populasi Aktual, Populasi Efektif, dan Laju Silang Dalam Per Generasi}

Tekanan silang dalam berpengaruh terhadap rendahnya daya tahan tubuh dan kinerja reproduktivitas ternak, serta menurunnya kondisi kesehatan ternak [22]. Hal ini tentunya berdampak terhadap tingginya angka kematian ternak pada periode embrio, pre-natal, maupun pasca kelahiran sampai periode pra-sapih [23]. Dengan demikian tekanan silang dalam akan berpengaruh terhadap status populasi ternak pada suatu wilayah. Suatu populasi dapat bertahan apabila laju silang dalam per generasi lebih kecil atau sama dengan $1 \%$ [24]. Ukuran populasi aktual, populasi efektif, dan laju silang dalam per generasi kerbau lokal di Kecamatan Waeapo Kabupaten Buru dapat dilihat pada Tabel 3 di bawah ini.

Tabel 3. Populasi aktual dan efektif, serta laju silang dalam per generasi kerbau lokal di Kecamatan Waeapo.

\begin{tabular}{|c|c|c|c|c|}
\hline \multirow[b]{2}{*}{ No } & \multirow[b]{2}{*}{ Peubah } & \multicolumn{2}{|c|}{ Desa } & \multirow{2}{*}{$\begin{array}{c}\text { Jumlah } \\
\text { (Kecamatan Waeapo) }\end{array}$} \\
\hline & & Waenetat & Wanareja & \\
\hline 1 & Jumlah Kerbau Jantan Dewasa (Ekor) & 32 & 38 & 70 \\
\hline 2 & Jumlah Kerbau Betina Dewasa (Ekor) & 86 & 74 & 160 \\
\hline 3 & Populasi Aktual (Ekor) & 118 & 112 & 230 \\
\hline 4 & Jumlah Populasi Efektif (Ekor) & 93 & 100 & 194 \\
\hline 5 & Laju Inbreeding $(\Delta \mathrm{F})(\%)$ & 0.54 & 0.5 & 0.26 \\
\hline
\end{tabular}

Populasi aktual adalah jumlah ternak jantan dan betina dewasa yang digunakan untuk proses perkawinan yang akan menghasilkan bibit [10]. Jumlah populasi aktual $(\mathrm{Na})$ kerbau di Kecamatan Waeapo adalah 230 ekor. Populasi terbesar berada di Desa Waenetat sebanyak 118 ekor, diikuti Desa Wanareja sebanyak 112 ekor. Sedikit berbeda dengan hasil penelitian Syahputra dkk. (2019), dimana ukuran populasi actual kerbau Murrah yang dimiliki BPTU-HPT Siborong-siborong dan peternak di Kabupaten Deli Sumatera Utara sebanyak 124 ekor [4]. Perbedaan ukuran populasi aktual ini tergantung lokasi dan sistem pemeliharaan [10].

Ukuran populasi efektif kerbau lokal di Kecamatan Waeapo Kabupaten Buru adalah sebesar 194 ekor. Hasil perhitungan nilai laju silang dalam per generasi $(\Delta \mathrm{F})$ sebesar $0,26 \%$. Hasil ini menunjukkan bahwa tekanan silang dalam (inbreeding) per generasi belum parah terjadi pada populasi kerbau di Kecamatan Waeapo. Dimana kenaikan $1 \%$ dari tingkat inbreeding per generasi akan menyebabkan menurunkan produktivitas performa ternak seperti bobot badan atau daya tahan tubuh yang rendah [8]. Dalam jangka panjang kecenderungan peningkatan silang dalam dapat saja terjadi jika populasi tetap dalam keadaan terisolir (tertutup) kemudian diikuti oleh sistem perkawinan yang tidak terkontrol [4]. Dengan rasio jantan betina kerbau dewasa sebesar 1 :
2,29, maka kemungkinan besar bahwa keturunan merupakan individu inbreed dapat terjadi. Silang dalam tidak dikehendaki karena dapat menurunkan produktivitas ternak. Hal ini merupakan salah satu langkah kebijakan perbibitan ternak yang dilakukan Pemerintah dan mengacu pada UU No. 2 Tahun 1999 dan PP No. 5 Tahun 2000 bahwa Pemerintah memiliki kewenangan mencegah terjadinya silang dalam (inbreeding) yang dapat mempengaruhi penyediaan bibit di masa mendatang. Banyaknya pejantan juga tidak efesien dalam segi ekonomi. Perbandingan jantan : betina diusahakan adalah 1:81o ekor [25].

\section{Kesimpulan}

Berdasarkan hasil penelitian dapat disimpulkan (1) populasi kerbau yang terdapat di Kecamatan Waeapo sebanyak 374 ekor dengan komposisi berikut anak jantan 8,56\% ; anak betina 7,49\% (1,14:1), muda jantan 11,5\% ; muda betina 10,96\% (1,05:1), dan dewasa jantan $18,72 \%$; dewasa betina $42,78 \%(1: 2,29)$ ; (2) Ukuran populasi aktual kerbau lokal di Kecamatan Waeapo adalah 230 ekor, dengan ukuran populasi efektif sebesar 194 ekor ; (3) Laju silang dalam (inbreeding) per generasi kerbau di Kecamatan Waeapo adalah 0,26\%. Mengindikasikan bahwa status populasi kerbau belum terjadinya silang dalam (inbreeding). 


\section{Referensi}

[1] G. Ciptadi, M. Mudawamah, V. M. A. Nurgiartiningsih, S. Wahjuningsih, Rr. F. D. Listiani, Susiati, L. Hakim, and A. Budiarto, "Reproduction Performance and Phenogram Analysis of Local Swamp Buffalo in East Java with A Case of Inbreeding Based on Phenotypic and DNA-RAPD". AIP Conference Proceedings 2021, 070009 (2018).

[2] S. H. Abdel-Aziem, L. M. Salem, M. S. Hassanane, and K. F. Mahrous, "Genetic Analysis between and within Three Egyptian Water Buffalo Populations Using RAPD-PCR", Journal of American Science, vol. 6, no. 6, pp. 217-226, 2010.

[3] E. Erdiansyah, "Keragaman Fenotipe dan pendugaan jarak Genetik Antara Subpopulasi Kerbau Rawa Lokal di Kabupaten Dompu, Nusa Tenggara Barat", Prosiding Seminar dan Lokakarya Nasional Usaha Ternak Kerbau Peningkatan Peran Kerbau dalam Mendukung Kebutuhan Daging Nasional, pp. 55-67, Tana Toraja, 24-26 Oktober 2008.

[4] M. A. Syaputra, S. Umar, and A. Gunawan, "Efek Silang Dalam Terhadap Ukuran Tubuh Kerbau Murrah”, Jurnal Ilmu dan Teknologi Peternakan Tropis, vol. 6, no. 3, pp. 382-387, 2019.

[5] E. M. Sari, M. A. N. Abdullah, and Sulaiman, "Kajian Aspek Teknis Pemeliharaan Kerbau Lokal Di Kabupaten Gayo Lues”, Jurnal Agripet, vol. 15, no. 1. pp. 57-6o, 2015.

[6] E. J. Warwick, J. M. Astuti, and W. Hadjosubroto, Pemuliaan Ternak, IV. . Cetakan Keempat. Yogyakarta: Gadjah Mada University Press, 1990.

[7] A. Y. Ismail, I. Nasihin, and D. Juhendar, "Struktur Populasi dan Sebaran Serta Karakteristik Habitat Huru Sintok (Cinnamomum sintocbl) Di Resort Cilimus Taman Nasional Gunung Ciremai, Jurnal Wanaraksa, vol. 9, no. 2, pp. 20-29, 2015.

[8] Rusfidra, R. Zein, and A. M. A Hasibuan, "Ukuran Populasi Efektif, Ukuran Populasi Aktual dan Laju Inbreeding Per Generasi Itik Lokal di Kecamatan Tilatang Kamang Kabupaten Agam”, Jurnal Peternakan Indonesia, vol. 14, no. 3, pp. 4651-465, 2012.

[9] I. S. L. Tobing, “Teknik Estimasi Ukuran Populasi Suatu Spesies Primata", Jurnal Us Vitalis, vol. 1, no. 1, pp. 43-52, 2008.

[10] Subandriyo, "Pengelolaan Data Plasma Nutfah Ternak", Buletin Plasma Nutfah, vol. 10, no. 2, pp. 90-100, 2004.

[11] C. H. M. Malhado, A. C. M. Malhado, P. L. S. Carneiro, A. A. Ramos, D. P. Ambrosini, and A. Pala, "Population Structure and Genetic Variability In the Murrah Dairy Breed of Water Buffalo In Brazil Accessed Via Pedigree Analysis",
Tropical Animal Health Production, vol. 44, no. 8, pp. 1891-1897, 2012.

[12] N. Smitz, D. Cornélis, P. Chardonnet, A. Caron, $M$ de Garine-Wichatitsky, F. Jori, A. Mouton, A. Latinne, L. Pigneur, M. Melletti, K. L. Kanapeckas, J. Marescaux, C. L. Pereira, and J. Michaux, "Genetic Structure Of Fragmented Southern Populations of African Cape Buffalo (Syncerus caffer caffer)", BMC Evolutionary Biology, vol. 14, no. 203, pp. 1-19, 2014.

[13] Subandriyo, "Konservasi Sumberdaya Genetik Ternak: Pertimbangan, Kriteria, Metoda dan Strategi”, Lokakarya Nasional Pengelolaan dan Perlindungan Sumber Daya Genetik di Indonesia: Manfaat Ekonomi untuk Mewujudkan Ketahanan Nasional, pp. 124-137, Pusat Penelitian dan Pengembangan Peternakan Bogor, 13-14 Ferbuari 2010.

[14] M. L. Santana Jr, R. R. Aspilcueta-Borquis, A. B. Bignardi, L. G. Albuquerque, and H. Tonhati, "Population structure and effects of inbreeding on milk yield and quality of Murrah buffaloes", J. Dairy Sci, vol. 94, pp. 5204-5211, 2011.

[15] R. Rukmana, Beternak Kerbau Potensi dan Analisis Usaha, Semarang : Aneka Ilmu, 2003.

[16] M. B. Hamilton, Population Genetics, West Sussex PO19 8SQ UK: Blackwell Publishing John Wiley \& Sons Ltd, 2009.

[17] C. Talib, T. Herawati, and Hastono, "Strategi Peningkatan Produktivitas Kerbau melalui Perbaikan Pakan dan Genetik", WARTAZOA, vol. 24, no. 2, pp. 83-96, 2014.

[18] M. Drost, "Bubaline versus bovine reproduction", Theriogenology, vol. 68, pp. 447-449, 2007.

[19] A. Budiarto, and G. Ciptadi, "The Productivity and Natural Increase of Swamp Bufallo In District malang", AIP Conference Proceedings 2021, 070009 (2018).

[20] Marsudi, Sulmiyati, T. D. Khaliq, D. U. Fahrodi, N. S. Said, and H. M. Rahmaniah, "Dinamika Populasi Ternak Kerbau Di Lembah Napu Poso Berdasarkan Penampilan Reproduksi, Output Dan Natural Increase", AGROVETERINER, vol. 5, no. 2, pp. 109-117, 2017.

[21] A. Ikun, "Faktor-Faktor yang Mempengaruhi Tingkat Populasi Ternak Kerbau di Kecamatan Biboki Anleu Kabupaten Timor Tengah Utara”, Journal of Animal Science, vol. 3, no. 3, pp. 38-42, 2018.

[22] K. N. Paige, “The Functional Genomics of Inbreeding Depression: A New Approach To An Old Problem", Bioscience, vol. 6o, no. 4, pp. 267277, 2010.

[23] P. Gullstrand, "Control of Inbreeding in Dairy Cattle in the Genomic Era", Bachelor Thesis of Swedish University of Agricultural Sciences, Uppsala Swedia, 2015 .

[24] N. Carolino, and L. T. Gama, "Inbreeding Depression on Beef Cattle Traits: Estimate, 
Linearity of Effects And Heterogene-Ity Among Sire-Families", Genetic Seletion Evolution, vol. 40, pp. 511-527, 2008.

[25] Departemen Pertanian, Road Map Perbibitan Ternak. Direktorat Perbibitan, Jakarta: Direktorat Jenderal Peternakan, 2008.

[26] [BPS] Badan Pusat Statistik Kabupaten Buru, Kecamatan Waeapo Dalam Angka Tahun 2019, Namlea: BPS Kabupaten Buru, 2019. 